\title{
ARREST REQUIREMENT FOR ADMINISTERING BLOOD TESTS
}

The intoxicated driver has become one of the most serious problems on the nation's highways. Recent blood tests performed on fatally injured drivers ${ }^{1}$ indicated that between sixty-five and seventyfive percent had alcohol concentrations in their blood of over 0.15 percent, ${ }^{2}$ an amount above the minimum required for a finding of intoxication. ${ }^{3}$ It has been suggested that the best method of dealing with drunken driving is to provide stronger law enforcement which will increase the potential drunken driver's expectation of being detected and convicted. ${ }^{4}$ This suggestion would require increased effectiveness in the investigatory procedures such as blood tests and other scientific means used by the police to detect the level of alcohol consumption. Although the use of such scientific tests clearly must meet the fourth amendment's requirement that a search be reasonable, ${ }^{5}$ the courts have not yet articulated the precise conditions under which the requirement is met. This note will explore the existing state requirements and the emerging constitutional requirements for administering blood tests.

\section{State Laws Dealing With Intoxicated Drivers}

Driving while intoxicated is a criminal offense in every state. ${ }^{6}$ At least forty-six states have adopted the language of the Uniform

1. Jacobsen v. International Transport, Inc., 391 F.2d 49 (8th Cir.), cert. denied, 393 U.S. 833 (1968), held that a blood test taken from a corpse was not an unreasonable search and seizure within the fourth amendment.

2. Cramton, Driver Behavior and Legal Sanctions: A Study of Deterrence, 67 Mich. L. REv. 421,437 (1969).

In order to reach a $0.10 \%$ concentration of alcohol in the blood, a $150 \mathrm{lb}$. person would have to drink $71 / 2$ ounces of 80 proof liquor in one hour. The same person would have to drink 10 ounces of 80 proof liquor in one hour to reach a $0.15 \%$ concentration level. Walker, King, Neilson \& Turkel, Alcohol and Other Factors in California's Highway Fatalities, 14 J. For. Scr. 429 (1969).

3. See note 14 infra and accompanying text.

4. See Breithaupt v. Abram, 352 U.S. 432, 439 (1957); Cramton, supra note 2, at 438-41. Professor Cramton warns, however, that certain other factors must be considered in reaching the precise level where the effectiveness of legal deterrence mechanisms is maximized. For example, the effectiveness of each sanction as well as the likelihood of enforcement will vary with different groups and classes in society. Also, the severity of the sanctions can reach a point of diminishing return when the severity of the penalty is out of proportion to the seriousness with which society views the unlawful activity and those responsible for enforcing the law become less likely to seek a conviction.

5. Schmerber v. California, 384 U.S. 757 (1966).

6. R. Erwin, Defense of Drunk Driving Cases $\$ 1.01$, at 4 (2d ed. 1966). 
Vehicle Code in labeling the specific offense as driving "under the influence of intoxicating liquor." Due to the many degrees of intoxication and the different effects which alcohol has upon different individuals the courts have found it difficult to verbalize a precise test of "under the influence." Generally, the state is required to show that the -defendant drank enough alcohol, regardless of the amount, to have sustained substantial mental or physical impairment. ${ }^{8}$ The state, however, does not have to show that such impairment actually interfered with the driver's operation of the vehicle at the time he was apprehended. Public policy demands that the drinking driver be stopped at some point prior to proving himself an actual menace to others on the highway. ${ }^{9}$ Yet, as a practical matter, proof of actual interference with the defendant's driving may be necessary to convince the jury that he was "under the influence." Absent some quantitative test of his impairment, such as a blood test, prosecutions for drunken driving have had to rely on such evidence as slurring of speech, smell of the breath, and exaggerated or uncontrolled mannerisms. While these evidentiary facts have been generally sufficient to establish probable cause for arrest, ${ }^{10}$ they have generally not sufficed to prove the defendant's guilt beyond a reasonable doubt."

Scientists are in agreement that the blood test is the most effective scientific method of detecting the amount of alcohol a person has consumed. ${ }^{12}$ In order to overcome the evidentiary problems of proving intoxication, many states have adopted legislation which would give the results of blood tests the effect of rebuttable presumptions as to guilt of criminal charges. ${ }^{13}$ The general rule has been that anyone with

7. UNIFORM VEHICLE CODE ANN. § 11-902(a) (1967):

"It is unlawful and punishable as provided in section 11-902.2 for any person who is under the influence of intoxicating liquor to drive or be in actual physical control of any vehicle within this State." See generally KNOw THE LAw 60-86 (R. Donigan \& E. Fisher eds. 1958).

8. See, e.g., Dawkins v. Chavez, 132 Colo. 61, 285 P.2d 821 (1955); State v. Hightower, 238 La. 876, 116 So. $2 d 699$ (1959).

9. State v. Weeden, 94 R.1. 1, 2, 177 A.2d 182, 183 (1962). See generally R. Donigan, Chemcal Tests AND the LaW 4-8 (2d ed. 1966).

10. See, e.g., State v. Gillespie, 100 N.J. Super. 71, 241 A.2d 239 (App. Div. 1968).

11. See generally Comment, The Drinking Driver: An Approach to Solving a Problem of Underestimated Severity, 14 VILL. L. REv. 97 (1968). In Boston during 1964 only 27 out of 83 persons charged and brought to trial for driving while intoxicated were convicted without evidence of blood-alcohol concentrations. Id. at 103.

12. See generally Report of the Fourth International Conference on Alcohol and Traffic Safety. 1966 CRIM. L. REV. 69.

13. Most states apply the presumption only in cases of driving while under the influence of 
less than 0.05 percent alcohol in his blood is presumed not to be under the influence of alcohol, and anyone with a concentration level above 0.10 percent, or 0.15 percent in many states, is presumed to be under the influence of alcohol. ${ }^{14}$

Due to the effectiveness of the blood test in detecting intoxication, many persons have refused to take the test. For this reason most states have enacted so-called implied consent statutes. ${ }^{15}$ Under these statutes a person is deemed to have given his consent to a blood test in exchange for the privilege of driving on the highways; ${ }^{16}$ however, if the

alcohol. Several other states, however, apply the presumption to other criminal actions as well-for example, involuntary manslaughter. See R. DonIGAN, supra note 9, at 27.

14. UNIFORM VEHICLE CODE ANN. § 11-902(b) (1967):

Upon the trial of any civil or criminal action or proceeding arising out of acts alleged to have been committed by any person while driving or in actual physical control of a vehicle while under the influence of intoxicating liquor, the amount of alcohol in the person's blood at the time alleged as shown by chemical analysis of the person's blood, urine, breath, or other bodily substance shall give rise to the following presumptions: 1. If there was at that time 0.05 percent or less by weight of alcohol in the person's blood, it shall be presumed that the person was not under the influence of intoxicating liquor.

2. If there was at that time in excess of 0.05 percent but less than 0.10 percent by weight of alcohol in the person's blood, such fact shall not give rise to any pre umption that the person was or was not under the influence of intoxicating liquor, but sucb fact may be considered with other competent evidence in determining whether the person was under the influence of intoxicating liquor.

3. If there was at that time 0.10 percent or more by weight of alcohol in the person's blood, it shall be presumed that the person was under the influence of int oxicating liquor.

Some states have 0.15 percent concentration levels as presumptive of intoxication. See, e.g., Ariz. Rev. Stat. ANn. § 28-692 (Supp. 1971); Conn. Gen. Stat. ANn. § 14-227a (Supp. 1971); S.D. Complled LAws ANN. \$ 32-23-7 (1967); VA. CODE ANN. § 18.1-57 (Supp. 1970).

15. Ala. Code tit. 36, § 154(a) (Supp. 1969); Alaska Stat. § 28.35 .031 (1970); Ariz. Rev. Stat. ANN. § 28-691 (Supp. 1971); ARK. STAt. ANN. § 75-1045 (Supp. 1969); Cal. Vehicle Code § 13353 (West Supp. 1970); CoNN. Gen. STAT. ANN. § 14-227b (Supp. 1971); Fla. Stat. ANN. § 322.261 (1969); GA. Code ANN. § 68-1625.1 (Supp. 1970); Hawall Rev. LAwS § 286-15I (1968); IDAHO CODE ANN. § 49-352 (1967); IOWA CODE § 321 B.3 (1966); KAN. Stat. ANN. § 8-1001 (Supp. 1969); KY. Rev. Stat. § 186.565 (1968); LA. Rev. Stat. § 32:661 (Supp. 1970); ME. Rev. Stat. ANN. tit. 29, § 1312 (Supp. 1970); MASS. GeN. Laws ANN. ch. 90, § 24(f) (Supp. 1971); MINN. Stat. ANN. \$169.123 (Supp. 1971); Mo. REv. STat. \$564.441 (Supp. 1971); N.H. Rev. STAT. ANN. § 262-A:69(a) (1966); N.J. Rev. STAT. § 39:450.2 (Supp. 1971); N.M. STAT. ANN. § 64-22-2.6 (Supp. 1969); N.Y. Veh. \& Traf. Law $\S 1194$ (McKinney Supp. 1970); N.C. GeN. STAT. § 20-16.2 (1965); N.D. Cent. Code § 3920-01 (Supp. 1969); Omo Rev. Code ANN. § 4511.19 .1 (Page Supp. 1970); OKLa. Stat. ANN. tit. 47, § 751 (Supp. 1971); Ore. Rev. Stat. § 483.634 (197I); PA. Stat. Ann. tit. 75, § 624.1 (Supp. 1970); R.I. Gen. LAwS ANN. § 31-27-2.1 (1968); S.D. CoMpiled LAws ANN. § 32-2310 (Supp. 1967); TenN. Code ANN. \$ 59-1044 (Supp. 1970); UTAh Code ANN. § 4I-6-44.10 (Supp. 1969); VT. StaT. ANN. tit. 23, § 1188 (1967); VA. CoDE ANN. § 18.1-55.1 (Supp. 1970); W. VA. CODE ANN. § 17C-5A-1 (Supp. 1970).

16. See R. Donigan, supra note 9, at 310-11, citing UNIFORM VEHICLE CODE $\$$ 6-205.1(a) (1962):

(a) Any person who operates a motor vehicle upon the public highways of this State shall 
driver refuses to give his consent no test may be administered. Although in Schmerber v. California ${ }^{17}$ the Supreme Court indicated that consent is not a constitutional prerequisite for the administration of a lawful blood test, these statutes do not authorize unconsented blood tests since it is unclear how much physical. force can be used before the driver's due process rights are violated. ${ }^{18}$ The statutes, instead, provide other incentives to induce the driver's submission, most commonly the revocation of the driver's license upon his refusal. ${ }^{19}$ Since one might prefer the inconvenience of license revocation to a conviction for driving under the influence of alcohol, these statutes have not always proven successful in inducing submission and have been criticized as being overly burdensome on the police..$^{20}$ Some states have attempted to compensate for this weakness in their implied consent laws by making refusal to submit admissible into evidence against the driver at his trial for drunken driving. ${ }^{21}$

be deemed to have given consent, subject to the provisions of section 11-902, to a chemical test or tests of his blood, breath, or urine for the purpose of determining the alcoholic content of his blood if arrested for any offense arising out of acts alleged to have been committed while the person was driving or in actual physical control of a motor vehicle while under the influence of intoxicating liquor. . . .;

E. Fisher, Vehicle Traffic Law 60-61 (1961).

17. 384 U.S. 757 (1966).

18. See generally Mcintyre \& Chabraja, Intensive Search of a Suspect's Body and Clothing. 58 J. CRIM. L.C. \& P.S. 18, 25 (1967). at 311 .

19. E.g.. UNIFORM VeHICLE CODE $§ 6.205 .1$ (c) (1962), cited in R. Donigan, supra nolc 9,

20. See generally McIntyre \& Chabraja, supro note 18, at 24.

21. There seems to be no constitutional barrier to admitting such evidence. In Schmerber v. California, 384 U.S. 757 (1966) the Supreme Court held that the defendant had no constitutional right to object to an otherwise valid blood test. This situation is distinguishable from a case such as Griffin v. California, 380 U.S. 609 (1965) where the defendant's right to remain silent was jeopardized by allowing the prosecution to comment on the defendant's failure to testify. In that case the Court reasoned that such comment by the prosecution penalized the defendant for asserting his constitutional rights. In blood test cases, unlike Griffin, no constitutional right is being jeopardized by admitting into evidence the defendant's refusal to take a blood test.

Some statutes specifically allow admission into evidence of a refusal. See, e.g., N.C. GeN. STTAT. § 20-16.2(b) (1965); PA. Stat. AnN. tit. 75, § 624.1(h) (Supp. 1971).

Where there is no legislative mandate the courts have gone both ways. The rationale for admitting evidence of the refusal is that the refusal has the same probative value as other conduct after the commission of a crime such as an attempt to escape and concealment of evidence. $C f$., State v. Dugas, 252 La. 346, 211 So. 2d 285 (1968). See also C. McCormick, Evidence $\S \S 246,250$ (1954).

Other courts have refused to construe the statutes 'to allow admissibility absent express legislative intent. See, e.g., State v. Munroe, 22 Conn. Supp. 321, 171 A.2d 419 (Cir. Ct. 1961); 
New York was the first state to enact an implied consent statute. ${ }^{22}$ In Shutt v. McDuff $f^{23}$ a New York court held that the statute violated the driver's constitutional rights against unreasonable searches and seizures, since absent a requirement that the driver be placed under arrest prior to being subjected to the blood test, the statute "was absolutely lacking in reasonable safeguards against arbitrary and unreasonable actions by police officers." ${ }^{24}$ The state did not appeal the case, and the legislature subsequently enacted a new law which included the requirement that the driver be arrested prior to requiring his submission to the blood test. ${ }^{25}$ Most states have followed the present New York statute in requiring an arrest as a precondition to applying its implied consent law. ${ }^{26}$ In those states which require an arrest, the accused has an absolute right to refuse to submit to a blood test, and the state can neither revoke his license nor introduce his refusal into evidence at trial. ${ }^{27}$ Most states have interpreted the arrest requirement to be of constitutional and not merely statutory origin..$^{28}$

The issue whether an arrest prior to administering a blood test is constitutionally mandated is of importance to a state whether or not its implied consent statute contains an arrest provision, or, indeed, whether or not the state has enacted an implied consent statute. The scope of some consent statutes has been limited by judicial interpretation to the specific crime of driving under the influence. ${ }^{29}$ Thus, even though an implied consent statute with an arrest requirement is in force, there are still instances, such as those involving the crime of involuntary manslaughter or criminal

State v. Ingram, 67 N.J. Super. 21, 169 A.2d 860 (Passaic County Ct. 1961); People v. Stratton, 286 App. Div. 323, 143 N.Y.S.2d 362 (1955), affd, 1 N.Y.2d 664, 133 N.E.2d 516, 150 N.Y.S.2d 29 (1956).

22. Act of April 19, 1953, ch. 854, \& 71-a, [1953] N.Y. Laws 1876.

23. 205 Misc. 43, 127 N.Y.S.2d 116 (Sup. Ct. 1954).

24. Id. at 51-52, 127 N.Y.S.2d at 126-27.

25. N.Y. VEH. \& TRAF. LAW § 1194 (McKinney Supp. 1970).

26. See statutes at rote 15 supra excepting lowa CODE ANN. § 321 B.3 (1966) (although this provision requires an arrest prior to requesting that a conscious driver submit to a blood test, no arrest is required prior to administering a blood test to an unconscious driver); N.J. REV. STAT. § 39:4-50.2 (Supp. 1971).

27. See, e.g., State v. Cruz, 21 Utah $2 \mathrm{~d} 406,446$ P.2d 307 (1968).

28. See, e.g., State v. Towry, 26 Conn. Supp. 35, 210 A.2d 455 (Super. Ct. 1965); State v. Cruz, 21 Utah 2d 406, 446 P.2d 307 (1968); cf. State v. Kroening, 274 Wis. 266, 79 N.W.2d 810 (1956).

29. Compare State v. Capelle, 285 Minn. 205, 172 N.W.2d 556 (1969) and State v. Aarhus, 80 S.D. 569, 128 N.W.2d 881 (1964) with People v. Young, 42 Misc. 2d 540, 248 N.Y.S.2d 287 (Weschester County $\mathrm{Ct}$. 1964). 
negligence, where the constitutional question as to the validity of the administration of a blood test will be applicable..$^{30}$ More importantly, however, since the arrest requirement has been incorporated into the implied consent law on the assumption that it is of constitutional origin, if the Constitution in fact requires something less, the need for more effective law enforcement may dictate amending the laws. ${ }^{31}$ In the three jurisdictions which require no arrest prior to administering the test ${ }^{32}$ and in those jurisdictions with no implied consent statute, the importance of determining if there is a constitutional requirement is obvious.

\section{The Application of Fourth Amendment Standards}

The fourth amendment prohibits "unreasonable searches and seizures." ${ }^{33}$ Furthermore, no warrants can be issued except upon probable cause. ${ }^{34}$ The warrant requirement has been interpreted to mean that a search can be performed only after a warrant has been issued by a judicial officer who has determined that probable cause exists. ${ }^{35}$ There are, however, two exceptions to the general warrant requirement. A police officer can perform a warrantless search when it is incident to a lawful arrest. ${ }^{36}$ Likewise, a warrantless search is permitted when special circumstances exist such that a delay in seizing

30. One might argue the logical extension of the implied consent rationale would be to allow blood tests without an arrest or search warrant since the driver could be deemed to have waived his constitutional rights upon accepting a driver's license from the state. No court has taken the implied consent tationale that far. Cf. State v. Dennington, 51 Del. 322, 164 A.2d 865 (1960).

Certainly there is a serious question whether such a waiver of constitutional rights would be found valid. The automobile has become such a necessary item in modern life, that the individual would have no real choice if he had to choose between waiving his protection from arbitrary searches and seizures and not being able to drive. Such consent would lack any real volitional content. See generally Van Alstyne, The Demise of the Right-Privilege Distinction in Constitutional Law, 81 HARv. L. REv. 1439 (1968).

31. Although the Virgin Island's statute states that an arrest is a prercquisite to a blood lest, the courts have construed arrest to mean only that the defendant be under some sort of police custody. See Virgin Islands v. Quinones, 301 F. Supp. 246 (D.V.I. 1969).

32. Id., State v. Findlay, 259 Iowa 733, 145 N.W.2d 650 (1966); State v. Macuk, 57 N.J. I, 268 A.2d 1 (1970). See also People v. Huber, 232 Cal. App. 2d 663, 43 Cal. Rptr. 65 (Dist. Ci. App. 1965) (California subsequently enacted an implied consent statute which requires the test to be made incident to an arrest. CAL. VehicLe Code $\S 13353$ (West Supp. 1970).

33. U.S. Const. amend. IV.

34. Id.

35. See, e.g., Spinelli v. United States, 393 U.S. 410 (1969); Aquilar v. Texas, 378 U.S. 108

(1964); Jones v. United States, 362 U.S. 257 (1960).

36. See, e.g., Beck v. Ohio, 379 U.S. 89 (1964). 
the evidence would risk its destruction or removal from the jurisdiction. ${ }^{37}$

In Breithaupt v. Abram $^{38}$ the Supreme Court rejected the petitioner's claim that his fourth and fourteenth amendment rights were violated by a warrantless blood test not taken incident to his arrest ${ }^{39}$ because, regardless of the validity of his claim, the exclusionary rule for illegally obtained evidence did not apply in state court proceedings..$^{40}$ The Court also rejected the petitioner's fourteenth amendment due process claim, holding that a blood test performed in a hospital environment did not "shock the conscience" of the Court. ${ }^{41}$ Because blood tests were said to have become too routine a procedure in today's world to be considered brutal, ${ }^{42}$ the Court distinguished blood tests administered in a hospital environment from forced stomach pumping, declared violative of the fourteenth amendment in Rochin v. California. ${ }^{43}$

Breithaupt is still authoritative to the extent that it held properly administered blood tests are not shocking to the conscience of the Court. However, the exclusionary rule was subsequently extended to state court proceedings, ${ }^{44}$ and in Schmerber $y$. California ${ }^{45}$ blood tests were held to be searches within the meaning of the fourth and fourteenth amendments. ${ }^{46}$ In that case Schmerber was taken to a

37. See, e.g., Henry v. United States, 361 U.S. 98 (1959).

38. 352 U.S. 432 (1957).

39. The prohibition against unreasonable searches and seizures had already been incorporated into the fourteenth amendment so as to prevent unreasonable intrusions by state officers. See Wolf v. Colorado, 338 U.S. 25, $27-28$ (1949).

40. 352 U.S. at 434 . The exclusionary rule was first enunciated by the Supreme Court in Weeks v. United States, 232 U.S. 383 (1914), in which case the Supreme Court held that evidence obtained by federal officers in a manner which contravened the defendant's fourth amendment rights could not be introduced into evidence at this subsequent trial in federal court. By disallowing the admission of unlawfully seized evidence the Court hoped to reduce the incentive for making unlawful searchs and seizures.

Although the prohibition against unlawful searches and seizures was incorporated into the fourteenth amendment and made applicable to the states, the Supreme Court initially refused to extend the exclusionary rule to state court procedings. See Wolf v. Colorado, 338 U.S. 25 (1949). Some states later adopted such a rule, holding that blood tests taken without a search warrant and not incident to the defendant's arrest were unreasonable searches and seizures, and, therefore, not admissible at trial. See, e.g., State v. Dennington, 51 Del. 322, 164 A.2d 865 (1960).

41. 352 U.S. at 437.

42. Id. at 436 .

43. 342 U.S. 165 (1952).

44. Mapp v. Ohio, 367 U.S. 643 (1961).

45. 384 U.S. 757 (1966).

46. The Court also held that petitioner's fifth amendment right against self incrimination 
hospital after suffering injuries in an automobile accident. While at the hospital the investigating officer noticed that Schmerber's breath smelled of alcohol and that his eyes were glassy and bloodshot. The officer arrested Schmerber for driving under the influence of alcohol and over Schmerber's objection had a doctor perform a blood test. Schmerber was subsequently convicted. Reviewing that conviction, the Supreme Court held that the blood test was not an unreasonable search and seizure ${ }^{47}$ because it was incident to a valid arrest. ${ }^{48}$ While the Court said that even a valid arrest would not justify a general exploratory search into the accused's person, it found the search to be reasonable here because alcohol in the blood begins to dissolve shortly after drinking, thus constituting an emergency wherein any delay of the test in order to obtain a warrant would risk the destruction of the evidence. ${ }^{49}$

The emergency doctrine, upon which the Court in Schmerber seemed to rely in part, was first enunciated by the Court in Carroll $v$. United States. ${ }^{50}$ In Carroll the warrantless stop and search of a moving vehicle by police officers was held to be justified because the officers had probable cause to believe that contraband was being carried and because the vehicle was in transit, making it impossible for the officers to obtain a warrant prior to the search. ${ }^{51}$ The emergency doctrine was later extended to searches of vehicles that had come to rest at the suspect's home because of the great possibility that the vehicle would be moved before the officer could return with a search warrant. ${ }^{52}$

The Supreme Court in Schmerber did not explicitly state whether or not the emergency doctrine could be used to justify warrantless searches of the human body independent of an arrest, but several courts have relied on Schmerber in so applying the doctrine..$^{53}$ Serious questions arise, however, as to whether the application of the emergency doctrine in such a situation can protect the individual from

was not violated because the evidence was not communicative in nature. Id. at 760.65. See generally Note, Constitutional Law: Supreme Court Delineates the Relationship Between the Fourth and Fifth Amendments, 1967 DuKE L.J. 367.

47. 384 U.S. at 772.

48. Id. at 768.

49. Id. at 768-70.

50. 267 U.S. 132 (1925).

51. Id. at 153 .

52. Scher v. United States, 305 U.S. 251 (1938).

53. See note 32 supra and accompanying text. 
unreasonable governmental denials of liberty and privacy. In theory the emergency doctrine requires that the investigating officer have probable cause to believe that the suspect was drinking before he can request that a blood test be administered. In practice, however, without the independent determination of probable cause by a magistrate prior to the blood test, the defendant may be forced to suffer the inconvenience and embarrassment of an unlawful search, the consequences of which cannot be erased even if there is a subsequent finding that probable cause did not exist. If the officer does not have probable cause to believe that the suspect has been drinking but merely has a suspicion of such activity, the emergency doctrine provides no safeguard against his requesting that the suspect be given a blood test and then either arresting or releasing the suspect depending on the results of the test. The emergency doctrine thus acts as an incentive to the police to make investigatory searches without probable cause. 1t is this type of general investigatory search, infringing upon individual liberty and privacy, against which the fourth amendment is directed..$^{55}$ The emergency doctrine has been applied in auto search cases because there may be no other means of enabling the police to effectively combat the use of vehicles for transporting contraband. It should not be applied in blood test cases without an equally compelling reason.

\section{Application of the Emergency Doctrine}

Despite the potential problems in extending the emergency doctrine to blood tests, in State v. Findlay ${ }^{55}$ the Iowa Supreme Court upheld a warrantless blood test performed on an unconscious driver who was not under arrest. The court found the police officer's testimony that the defendant smelled of alcohol at the time of the blood test was sufficient to establish probable cause for the search of the suspect's blood. The existence of an emergency due to the evaporation of the alcohol was deemed sufficient to justify a warrantless search. The lowa court analogized the taking of blood to the warrantless search of moving vehicles. ${ }^{56}$ Application of the

54. Cf. Davis v. Mississippi, 394 U.S. 721 (1969).

Investigatory seizures would subject unlimited numbers of innocent persons to the harassment and ignominy incident to involuntary detention. Nothing is more clear than that the Fourth Amendment was meant to prevent wholesale intrusions upon the personal security of our citizenry . . . Id. at 726.

55. 259 lowa 733, 145 N.W.2d 650 (1966).

S6. Id. at 742, 145 N.W.2d at 656 . 
emergency doctrine to blood tests was said by the court to be even more compelling than in the case of vehicle searches, since the alcohol in the blood will not merely disappear but will be totally destroyed within two hours.57 The Findlay court also indicated that fourth amendment requirements might be less stringently applied in the case of blood tests than in other types of bodily invasions, reasoning that because no pain, suffering or injury was inflicted, such a "minor intrusion" into the body of the accused is not prohibited by the Constitution. ${ }^{58}$

The emergency doctrine relied upon by the court in Findlay has been the primary rationale upon which warrantless blood tests not incident to an arrest have been allowed.$^{59} \mathrm{~A}$ very practical distinction exists, however, between vehicle searches and blood tests. In the former situation the investigating officer himself is permitted to make the search at the scene, because it may well be physically impossible for him to leave in order to obtain a search warrant or an arrest warrant without risking the removal of the suspected contraband. In cases involving blood tests, however, the officer must seek the assistance of qualified medical personnel, ${ }^{60}$ which assumes his ability to leave the scene accompanied by the suspect. The limitations under which he operates are temporal rather than spatial. Time is a less severe limitation than is a requirement that he be in two places at once. Moreover, the time required for the blood test represents a more substantial infringement of the suspect's liberty than does that required for a vehicle search. In addition, the lag between the taking of the accused into custody and the administering of the blood test offers the officer an opportunity to make further observations of the suspect's behavior. Such observations can be introduced into evidence

57. Id.

58. Id. at 739,145 N.W.2d at 654 . "So long as the measures adopted do not amount to a substantial invasion of individual rights, society must not be prevented from seeking to combat this hazard to the safety of the public." Id. at 744, 145 N.W.2d at 657, quoting from People v. Duroncelay, 48 Cal. 2d 766, 772, 312 P.2d 690, 694 (1957).

59. See generally Note, Destruction of Evidence $-A$ Rationale for Blood Tests Without an Arrest?, 18 Stan. L. Rev. 243 (1965); 79 HaRv. L. Rev. 677 (1966).

60. There are two requirements any search must meet in order for the search to be reasonable. First, the search must be justified under the circumstances, either by warrant issued on probable cause, incident to a lawful arrest, or by an emergency situation. Second, the test must be performed in a reasonable manner. The Supreme Court has apparently assumed that, as applied to blood tests, the latter test of reasonableness requires that the blood test be performed by qualified medical personnel in a "medical environment." Schmerber v. California, 384 U.S. 757, 772 (1966). See also Breithaupt v. Abram, 352 U.S. 432 (1957). 
at trial. Although the fifth amendment requirement that the suspect be advised of his right to remain silent would prevent the officer from using this period for the purpose of interrogating the suspect without making an arrest, there is no protection against the police using this period for making in-custody investigations by observation. In State v. Gillespie $e^{61}$ a New Jersey court upheld the introduction into evidence of information obtained by a police doctor through such an incustody observation even though the defendant had been unlawfully arrested and detained. The arrest had been made without a warrant on charges that the accused was driving under the influence of alcohol, although the officer did not see the accused driving. Such an arrest is unlawful in New Jersey since a warrantless arrest for a misdemeanor can only be made if the offense was committed in the presence of the arresting officer. Nevertheless, the court applied the emergency doctrine to the evidence obtained, reasoning that because the characteristics and mannerisms caused by intoxication would be destroyed as sobriety returned, an emergency existed which justified the making of in-custody observations. Since the emergency doctrine operates independent of an arrest requirement the court held that the unlawfulness of the arrest did not affect the validity of the search. ${ }^{62}$ The net effect of such an application of the emergency doctrine to blood test cases is that the police can detain the suspect, make a warrantless blood test and observe his behavior, and then, having completed this in-custody investigation, decide whether to arrest the suspect based upon the results of the investigation. Vehicle searches, on the other hand, do not present a significant problem of detention since the time involved in stopping and searching the vehicle is of relatively short duration. Moreover, the risk of indiscriminate gathering of evidence during a vehicle search is offset by the severity of the limitations under which the police would otherwise be forced to operate. Because the emergency doctrine presents greater problems for the protection of the suspect's liberty in blood test cases than it does in vehicle search cases, an attempted analogy between these two situations is not altogether persuasive.

A further distinction between vehicle and body searches may be the degree of constitutional protection which the object being searched is accorded. In Findlay the blood test was characterized as only a

61. 100 N.J. Super. 71, 241 A.2d 239 (App. Div. 1968).

62. Id. at 86,241 A.2d at 247. 
"minor intrusion" into the suspect's privacy ${ }^{63}$ The Iowa court assumed that the suspect's person is under no greater constitutional protection in the emergency situation than is a vehicle. ${ }^{65}$ Subsequent decisions of the United States Supreme Court have indicated to the contrary.

In Chambers $v$. Maroney ${ }^{65}$ the Supreme Court upheld the validity of a warrantless vehicle search which was neither incident to arrest nor justifiable on the grounds of an emergency since the car was securely in police custody at the time of the search. The majority concluded that the search was reasonable because the auto could have been searched at the time of the arrest, and the mere fact that the police waited until the car was in their custody made the search no less reasonable. ${ }^{66}$ In speaking for the majority in Chambers, however, Justice White made it clear that the Court's test was not meant to be extended to searches of other types of property. He remarked that there is "a constitutional difference between houses and cars." 67 Although Justice White did not state what this difference is, certainly it is not merely one of mobility - the original justification for the emergency doctrine ${ }^{68}$ - since a vehicle held in police custody and a fixed structure such as a house are both reasonably certain of not being moved during the time a search warrant is being obtained. The constitutional distinction, rather, must be that the homeowner has a greater expectation of being secure in his privacy than does the car owner. The car is a public conveyance in the sense that it is relatively open to public exposure and appears on the public highways. The home, however, is a place in which the individual expects to enjoy the maximum privacy that society will afford him. This same rationale should apply to the human body. ${ }^{69}$ Certainly the body is as intimate

63. 259 Iowa at 739 , 145 N.W.2d at 654 .

64. Id. at 742,145 N.W. $2 d$ at 656.

65. 399 U.S. 42 (1970).

66. In this case the defendant and three other persons were arrested on charges of armed robbery. The car in which the men were riding when they were arrested was not searched at the time of the arrest, but was taken to the police station where it was thoroughly searched without a warrant. The search produced evidence which linked the defendant and the others with several robberies.

67. 399 U.S. at 52.

68. See notes 50-52 supra and accompanying text.

69. "Search warrants are ordinarily required for searches of dwellings and absent an emergency, no less should be required where intrusions into the human body are concerned." Schmerber v. California, 384 U.S. 757, 770 (1966). 
and as central to one's privacy as is the home. ${ }^{70}$ The body may be more subject to public intrusions than the home in the sense that blood tests are required for marriage and for induction into the armed services; however, in terms of police interference with privacy in an accusatorial context there seems to be little difference in an individual's right to protection.

The Supreme Court's willingness to safeguard the right to bodily privacy is indicated by its decision in Davis $v$. Mississippi $i^{71}$ invalidating the warrantless fingerprinting of a suspect who had not yet been arrested. The Court recognized that fingerprinting was only a minor intrusion upon the defendant's personal security, ${ }^{72}$ but concluded that the fourth amendment's warrant requirement "would seem not to admit of any exception in the fingerprinting context."73 Admittedly, the Court distinguished this case from an emergency situation, ${ }^{74}$ there being no fear of destruction of the fingerprints. Nevertheless the differences inherent in the nature of the emergency involved in blood tests and vehicle searches and the greater degree of constitutional protection required of the individual's person leads to the tentative conclusion that a wholesale adoption of the emergency doctrine as applied to vehicle searches cannot be made as to blood tests. A conclusive answer to the question whether some greater procedural safeguard should be placed upon the administering of blood tests than would be required under the emergency doctrine cannot be had without determining what alternative to the emergency doctrine is available and whether the degree of protection that alternative gives justifies the burden which it places upon police investigations.

\section{Requirement of a Prior Arrest}

Implied consent statutes of most states require a valid arrest prior to the administration of a blood test..$^{75}$ The reason for requiring a prior arrest is that the blood test itself should not be a factor upon

70. The fourth amendment speaks of the right of the people "to be secure in their persons, houses, papers and effects." U.S. CoNsT. amend. IV. In Griswold v. Connecticut, 381 U.S. 484 (1965), the Court states that this and other guarantees of the Bill of Rights create "zones of privacy."

71. 394 U.S. 721 (1969).

72. Id. at 727 .

73. Id. at 728 .

74. Id. at 727 .

75. See note 26 supra and accompanying text. 
which the determination to arrest is made, and correspondingly, that probable cause should be established prior to the taking in order to prevent general investigatory searches into the suspect's person to determine whether he has been drinking. ${ }^{76}$ The requirement of a prior arrest almost always means a prior warrantless arrest in the blood test context, since the police will not be able to investigate the crime and obtain a warrant prior to taking the suspect into custody. The course of events following a warrantless arrest can take two directions. Since most states require that an officer making a warrantless arrest immediately present the suspect to a magistrate in order that he be charged with an offense, ${ }^{77}$ it would seem to be mandatory in those cases where a magistrate is available that the accused be brought before him unless the time involved would endanger the destruction of the alcohol concentration in the blood. Because the magistrate would be able to rule on probable cause prior to the test just as he would make a similar ruling prior to granting a search warrant, the chances that the application of the test will be arbitrary are lessened. Unrestricted application of the emergency doctrine, on the other hand, would require no such intervention by a magistrate, thus substantially increasing the possibility of an arbitrary interference with the suspect's liberty and privacy. The one exception to the normal train of events following a warrantless arrest would be in those cases where, either due to the time of the arrest or the distances involved, no magistrate is available. The blood test would have to be made prior to bringing the suspect before the magistrate in order to prevent the destruction of the alcohol, and the suspect would have to be held in custody until a magistrate is available. ${ }^{78}$ In terms of judicial administration, administering the blood test prior to bringing the suspect before a magistrate does not differ significantly from allowing an officer who has probable cause to believe that a suspect is intoxicated, to request a blood test under the emergency doctrine. In both situations a court or magistrate will have to determine after the suspect's liberty and privacy have been infringed, whether the

76. See notes 53-56 supra and accompanying text.

77. See, e.g., N.Y. CODE CRIM. PROC. \& 140.20 (McKinney 1970) ("without unnecessary delay"); N.C. GEN. STAT. § 15-46 (1965) ("immediately").

78. Such detention procedures have been enacted in many states. While some statutes provide for the suspect's release on bail until a magistrate's hearing can be arranged, such prehearing bail generally would not be available to one who is suspected of being under the influence of alcohol. See N.Y. CODE CRIM. PROC. $\$ 140.20$ (1970). 
arresting officer had probable cause either to make the arrest or to conduct the search. Determining probable cause is very difficult for a court regardless of the order of events. Generally, the only evidence of probable cause is the investigating officer's impression of the accused's condition and mannerisms at the time he is taken into custody, which evidence cannot be preserved for trial except by the officer's testimony. ${ }^{79}$ Thus a determination of probable cause both by the magistrate and at trial becomes in many instances a question of whom to believe, the officer or the defendant. ${ }^{80}$ Nevertheless, a warrantless arrest would help ensure that probable cause to conduct the blood test did in fact exist, since the officer is bound by his decision to arrest prior to the taking of the blood test. Unlike a search under the emergency doctrine, the arresting officer cannot have the test administered and then free the suspect until the test results indicate whether an arrest is justified; once the suspect has been arrested he cannot be released prior to a hearing before a magistrate. Since the subsequent test will act as a check on the soundness of his judgment in making the arrest, there is a greater degree of assurance than under the emergency doctrine that the officer will make a determination of probable cause at the time of the arrest. ${ }^{81}$ Where there is a long delay between the administration of the test and the formal arrest the courts have tended to invalidate the search. ${ }^{82}$ The underlying assumption seems to be that a long delay in arrest decreases the probability that the investigating officer had anything more than a mere suspicion that the driver was drinking and that the real basis for the arrest was the results of the blood test. ${ }^{83}$

79. See notes 9-11 supra and accompanying text.

80. See generally R. ERwIN, supra note 6, at §§ 7.01-.03.

81. Another possible deterrent both against unreasonable searches and seizures and unlawful arrests is the threat of a suit being brought against the police officer under 42 U.S.C. $\S 1983$ (1964) for deprivation of the suspect's rights. Such a threat may be more of a deterrent than the actual suit itself. Since the officer would have a defense if probable cause existed, the person bringing the suit may have some of the same evidentiary problems as bave plagued him in the situations discussed above. See generally Shapo, Constitutional Tort: Monroe v. Pape, and the Frontiers Beyond, 60 Nw. U.L. Rev. 277 (1965); Note, Tort Liability of Law Enforcement Officers Under Section 1983 of the Civil Rights Act, 30 LA. L. REv. 100 (1969).

82. See, e.g.. Mitchell v. State, 227 So. $2 \mathrm{~d} 728$ (Dist. Ct. App. Fla. 1969); Commonwealth v. Murray, 441 Pa. 22, 271 A.2d 500 (1970); State v. Capelle, 285 Minn. 205, 172 N.IV.2d 556 (1969); State v. Kroening, 274 Wis. 266,79 N.W.2d 810 (1957).

83. The delay, for example, might have stemmed from the arresting officer's awaiting the outcome of the test. The amount of time involved between taking the blood test and obtaining the results are dependent upon several factors. In ruzal areas where the sulfuric acid technique is used to analyze the alcohol content of the blood, the results cannot be obtained for two or three 
In jurisdictions which have not made an arrest a precondition for administering a blood test, the courts have not considered the time span between the search and the arrest. ${ }^{84}$ The emergency doctrine is independent of any arrest requirement in its application. Thus, even where the defendent was arrested without probable cause, the blood test would not be invalidated as fruit of the unlawful arrest so long as probable cause for conducting the search was determined to have existed. ${ }^{85}$ Without the requirement of a prior arrest the administering of a blood test seems open to those abuses already discussed. ${ }^{86}$

The requirement of an arrest prior to administering the blood test will vary with state law, since arrest procedures are not delineated in the Constitution. Generally an arrest can be made without a warrant where a felony has been committed and the arresting officer has probable cause to believe that the suspect has committed the crime. ${ }^{87}$ Likewise, in the case of misdemeanors an arrest can be made without a warrant if the crime was committed in the presence of the officer.$^{88}$ Thus, where mansiaughter is involved or where the officer sees the defendant driving in a reckless manner, an immediate warrantless arrest can be made. In such cases there is no reason for suspending the arrest requirement, since the officer is not burdened by the delay of obtaining a warrant and the defendant is afforded the minimal

hours. Since this test is generally performed by a local hospital not sufficiently staffed to maintain its laboratory at night, the blood sample has to be preserved until morning. In most medium sized communities, as well as in many rural communities, the most widely used analysis technique is the enzyme method which yields a result in thirty minutes. If the hospital performing the analysis maintains a night staff in its laboratory, the results of the test can be obtained rather quickly. In larger metropolitan hospitals chromatographic techniques of analysis are employed. The expensive equipment required for this technique makes its use prohibitive in less populated areas or where blood tests are not normally relied upon. The results of this technique can be obtained within ten to fifteen minutes. Due to great variance in the time involved to obtain the blood test results, the mere fact that the test was contemporaneous with the subsequent arrest may do very little to ensure that the arrest was made upon considerations independent of the blood test results. Telephone conversations with laboratory personnel at Watts Hospital, Durham, North Carolina.

84. See, e.g., Virgin Islands v. Quinones, 301 F. Supp. 246 (D.V.1. 1969); State v. Tolbert, 100 N.J. Super. 350, 241 A.2d 865 (Crim. Div. Middlesex Co. 1968); State v. Findlay, 259 lowa 733, 145 N.W.2d 650 (1966); People v. Huber, 232 Cal. App. 2d 663, 43 Cal. Rptr. 65 (Dist. Ct. App. 1965).

85. A police officer might have probable cause to believe that an individual is intoxicated, based on the individual's demeanor, while having no probable cause to believe that he has committed a particular offense.

86. See note 60 supra and accompanying text.

87. E.g., N.Y. CODE CRIM. Proc. \$ 140.10 (McKinney 1970).

88. E.g., N.J. Stat. ANN. § 39:5-25 (1961); PA. Stat. ANN. tit. 75, § 1204 (1960). 
protection of requiring the officer to commit himself by an affirmative act prior to the administering of a blood test.

A more serious burden is placed on the police in cases where there are no fatalities or where the of ficer does not see the suspect in the act of driving. If the crime is only a misdemeanor and is not committed in the officer's presence, most states require that an arrest warrant be obtained. ${ }^{99}$ Requiring the police to obtain an arrest warrant prior to arresting the suspect for driving under the influence of intoxicating liquor, however, is no less a burden upon successful police investigations than would be requiring a search warrant prior to the administration of a blood test. This problem has forced some states to relax their arrest requirement as one method to allow warrantless arrest in drunken driving cases. ${ }^{90}$

\section{CONCLUSION}

The Supreme Court's opinion in Schmerber did not clearly indicate the extent to which the emergency doctrine can be applied to the administering of a blood test prior to an arrest. The inherent connection between an individual's body and his fourth amendment right to be free of arbitrary infringements upon his privacy suggests that a higher degree of protection is needed in the case of blood tests than is offered by the emergency doctrine. The need is accentuated by the substantial infringement on an individual's liberty which is required merely to convey the individual to a location where the test may be properly administered.

Requiring that the police make a lawful arrest prior to taking the suspect into custody for a blood test should be the minimal constitutional standard under the fourth and fourteenth amendments. Such a standard places relatively little burden on the police since in many cases a warrantless arrest can be made. In those states where warrantless arrests for a misdemeanor not committed in the presence of an officer are not permitted, some changes in the arrest laws may be in order, ${ }^{91}$ but such changes are preferable to a lessening of the

89. Compare Colling v. Hjelle, 125 N.W.2d 453 (Sup. Ct. N.D. 1964), and State v. Nixon, 102 Ariz. 20, 423 P.2d 718 (1967) with State v. Tolbert, 100 N.J. Super. 350, 241 A.2d 865 (Crim. Div. Middlesex Co. 1968).

90. See, e.g., ARIz. Rev. Stat. ANN. § 13-1403 (Supp. 1970); N.D. Code ANN. § 29-06-15 (Supp. 1969).

91. See note 90 supra. The amendment to the Arizona statute exempts from the normal requirement that the arresting officer personally observe the commission of a misdemeanor, 
constitutional protection against arbitrary searches. A prior arrest requirement would give the suspect the minimum protection of separating the basis of his arrest from the blood test results. It would also place some restraint upon the police officer in requesting a blood test, since, depending on the circumstances, he would either have to take the suspect directly before a magistrate or have the test administered knowing that he had at least committed himself to making the arrest. In either event there would be some assurance that probable cause was based upon considerations independent of the blood test results. Without requiring a prior arrest there seems to be no alternative way of protecting individuals suspected of driving under the influence of alcohol from arbitrary denials of liberty and privacy.

those violations of its motor vehicle regulations which occurred prior to or following a traffic accident. Carried too far, of course, relaxation of the statutory arrest requirements would negate the requirement of an arrest prior to the administration of a blood test. 